\title{
TEACHER PERFORMANCE EVALUATION TECHNIQUES IN PUBLIC AND PRIVATE SECONDARY SCHOOLS IN SOUTH EAST NIGERIA
}

\author{
KENNETH K. OBASI AND ADANMA N. OHIA \\ (Received 2, October 2012; Revision Accepted 27, June 2014)
}

\begin{abstract}
Teacher performance assessment is critical to rational training and development. This study therefore examined the techniques adopted and the frequency of their utilization among public and private secondary schools in South East Nigeria. The design was descriptive. The population was 2,214 schools with 27,986 principals and teachers. 108 schools were sampled with 877 principals and teachers as respondents. Stratified random sampling technique was adopted, each state served as a stratum. The instrument for data collection was questionnaire. Percentage, mean and standard deviation were used to answer the research questions, while t-test was used for the hypothesis. The study revealed that all the seven techniques examined are all utilized by both schools, but the frequency is significantly more in private schools. The government in collaboration with the Teachers Registration Council of Nigeria (TRCN) should provide a legal framework that will ensure that teachers are regularly assessed. The personnel to carry out the exercise should be professionally trained.
\end{abstract}

KEYWORDS: Teacher performance, evaluation techniques, quality secondary education

\section{INTRODUCTION}

Organizational quality which is basically expressed in its output in terms of product or service is a function of the input - output process. Human resources are considered the most important factor in organizational life because it is the most active resource and every other resource depends on it for relevance and functionality. In the school, the teacher holds sway. He is very important in the teaching learning process. The quality of the teaching staff of any school, to a very great extent, determines the quality of that school. Santiago and Benavides (2009:3) succinctly captured it thus: "as the most significant resource in schools, teachers are critical to raise education standards". Quality is a continuous process because what is considered to be of quality today may cease to be tomorrow. One of the factors that guarantee staff (teacher) quality is continuous training and development.

The training and development of organizational manpower can only be rational and relevant if is carried out on the basis of needs. It is therefore through competency/performance assessment that a teacher's training needs can be properly identified. Performance appraisal is a systematic process of determining an employee's performance level. It identifies the individual's areas of strength and weakness. Performance appraisal measures skills and accomplishments with reasonable accuracy and uniformity. It provides a way to help identify areas for performance enhancement and to help promote professional growth. The process is to recognize achievement, to evaluate job progress and then to design training for further development of skills and strength.

Kenneth K. Obasi, Department of Educational Management, Faculty of Education, University of Port Harcourt, Port Harcourt, Nigeria.

Adanma N. Ohia, Department of Educational Management, Faculty of Education, University of Port Harcourt, Port Harcourt, Nigeria. 
Performance appraisal is the process of evaluating how well employers perform their jobs as compared to a set of standards and then communicating that information to those employees. This review is usually carried out periodically (Seanhan, 2010). Specifically, it identifies the gap between the expected performance level and the actual performance level. On the strength of this, Santiago and Benavides (2009) maintained that teacher evaluation can be interlinked with school arrangement to improve teaching process. They further added that results from teacher's assessment can be used to identify teaching needs and contribute to the definition of the school plan in order to improve the teaching process in the school. It is integrated and embedded in the system of school quality assurance mechanism.

\section{The Problem}

The quest for the delivery of quality education at all levels has continued to be a wild-goose chase despite efforts by successive governments. One factor that has remained a pain in the neck of quality secondary education is the quality of teaching personnel. There are so many unqualified and inexperienced teachers in the system. The Federal Ministry of Education once disclosed that 56,294 out of a total population of $208,497(27 \%)$ secondary system teachers are not qualified to teach (Anikulapo, 2007). This number excludes those in private secondary schools. Considering the critical role the teachers play in the teaching - learning equation, poor teacher quality obviously exacerbates poor quality education with its attendant negative consequences on the quality of the system's products and the society at large. The study's concern therefore is to know if the teacher's performance is regularly appraised in order to identify their specific need areas for necessary action. The outcome of the assessment would therefore make the training and development programmes relevant, rational and need - based in order to ensure quality.

\section{Purpose of Study}

On the strength of the above stated problem, this study aimed to find out the following:

- The techniques utilized for performance appraisal carried out to determine the training needs of teachers.

- How frequently the competency assessment techniques are utilized.

\section{Research Questions}

- What are the competency assessment techniques utilized to determine the training needs of the teachers?

- How regular are the techniques utilized?

\section{Hypothesis}

There is no significant difference between public and private secondary schools with respect to the frequency of utilization of the competency assessment techniques.

\section{Literature Review}

Performance appraisal is one of the strategic management functions aimed at ensuring continuous improvement of employees' performance. Basically, it serves dual purposes: administrative and developmental, but this study focuses on the developmental aspect of it. Performance appraisal is the systematic process of determining employer's performance level, and when properly carried out, it reveals the difference between the expected performance and actual performance levels (Obasi, 2011). Managing employee performance is an integral part of the tasks that all managers and rating officials perform throughout the year. It is as important as managing financial resources and programme outcomes because employee's performance or the lack thereof has a profound effect on both the financial and programme components of any organization. Performance management therefore is a systematic process of planning work and setting expectations, continually monitoring performance, periodically rating performance in a summary fashion and rewarding good performance while poor performance is remedied.

$$
\text { Chapman (2011) posited that }
$$
performance appraisals are essential for the effective management and evaluation of staff. It helps develop individuals, improve organizational performance through monitoring of standards. Generally, it reviews each individual's performance against objectives and standards over a period of time. It provides a formal, recorded, regular review of an individual's performance and a plan for future development. Archer North Performance Appraisal System (2010) posited that it is a structured formal interaction between a subordinate and supervisor that usually takes the form of periodic interview (annual or semi annual) in which the work performance of the subordinate is examined and discussed. It is undertaken with a view to 
identifying strengths and weaknesses as opportunity for improvement and skills development.

The teaching profession is not an exception in this regard. Performance appraisal of teachers is important in understanding each teacher's abilities and competencies. It helps to measure the performance of teachers and to evaluate their contribution towards the attainment of specified school goals. Effective teachers are capable of inspiring significantly greater learning gains in their students when compared with their weaker colleagues. Value-added assessment studies in Tennessee show that the difference in achievement between students who attended classes taught by low-quality teachers for three consecutive years is sizeable. (Sanders and Rivers, 1996). Performance appraisal takes into account the past performance of teachers and focuses on the improvement of the future performance (Rehman 2009). Teacher performance appraisal system provides teachers with meaningful appraisals that encourage professional learning and growth. Meaningful teacher evaluation involves an accurate appraisal of the effectiveness of teaching, its strengths and areas for development, followed by feedback, coaching, support and opportunities for professional development. The processes concentrate on the core activity of teaching typically covering areas such as planning and preparation, the classroom environment and instruction itself, contribution to school development and professional development activities (Santiago \& Benavides, 2009). The process is designed to foster teacher development and identify opportunities for additional support where required (The Elementary Teachers Federation of Ontario, 2011).

Assessing training and development needs is a complex and sensitive programme. It is not a straight forward exercise that can be successfully accomplished with ease. It requires quality time for planning and preparation. Some techniques have been developed by experts for this identification exercise. They include interview technique, questionnaire, appraisal report, classroom observation. They could be used singly or in a combination of two or more. The technique used is dependent on the resource at the disposal of each school.

\section{Methodology}

The descriptive survey was adopted. Both descriptive and inferential statistical techniques were used. The population comprised all the public and private secondary schools in South Eastern States of Nigeria. They were two thousand two hundred and fourteen $(2,214)$. One thousand two hundred and thirty one $(1,231)$ are public while nine hundred and eighty three (983) were private. The study sampled twenty five percent $(25 \%)$ of all the Local Government Areas from which twenty percent $(20 \%)$ of all the schools were sampled. One hundred and eight (108) schools were therefore sampled. They were sixty two (62) public and forty six (46) private schools. From the sampled schools, all the principals and twenty five percent $(25 \%)$ of the teachers were sampled as respondents (one hundred and eight principals and seven hundred and sixty nine (769) teachers. They were eight hundred and seventy seven respondents in all.

Stratified random sampling technique was adopted. Each state served as a stratum. The instrument for data generation was questionnaire that had three sections: the bio data of the schools, the different performance assessment techniques and the frequency of utilization of the techniques. The instrument had forty one items on the whole. The response options were Very Regular, Occasionally, Rarely and Not at all; To a great extent, To a moderate extent, To a minimal extent and not al all; Very true, True, Not true and Very untrue. The modified four - Likert scale was used for rating. Percentage, mean and standard deviation were used to answer the questions while $t$ - test was used to test the hypothesis.

\section{Answers to Research Questions}

Research Question I: What are the competency assessment techniques utilized to determine the training needs of the teachers? 
Table 1: Frequency and percentage distribution of the opinions of the respondents on the competency assessment techniques utilized in determining teachers training needs.

\begin{tabular}{|c|l|c|c|c|c|}
\hline S/ & APPROACHES/TECHNIQUES & \multicolumn{2}{|c|}{ PUBLIC } & \multicolumn{2}{l|}{ PRIVATE } \\
\hline & $\quad$ Freq & $\%$ & Freq & $\%$ \\
\hline 1 & Staff development interview schedule & 121 & 54.0 & 87 & 54.0 \\
\hline 2 & $\begin{array}{c}\text { Questionnaire returned to the staff development } \\
\text { coordinator }\end{array}$ & 166 & 71.2 & 133 & 82.6 \\
\hline 3 & Staff annual appraisal report & 165 & 73.0 & 122 & 75.8 \\
\hline 4 & Training needs audit carried by consultants & 156 & 69.3 & 116 & 73.0 \\
\hline 5 & Use of staff development committee report & 195 & 88.6 & 149 & 92.5 \\
\hline 6 & Classroom observation by supervisors & 146 & 66.1 & 143 & 88.8 \\
\hline 7 & Ad hoc assessment by the principal & 131 & 59.8 & 139 & 86.9 \\
\hline
\end{tabular}

A total of seven strategies were examined. The frequency and percentage distribution of positive responses on each of the strategies clearly reveal that all of them are utilized in both public and private secondary schools in determining staff training needs. This is because the percentage of those who responded "yes" to the strategies in public schools ranges between $54 \%$ and $88.6 \%$, while that of private schools ranges between $54 \%$ and $92.5 \%$. These strategies include interviews, activities of staff development coordinators, classroom observation. Others are assessment by the principal and audits by consultants.

Research Question II: How regular are these competency assessment techniques/approaches utilized?

Table 2: Mean and standard deviation of respondents of the Frequency of utilization of competency assessment techniques in determining the training and development needs of teachers.

\begin{tabular}{|c|l|c|c|c|c|}
\hline S/ & APPROACHES/TECHNIQUES & \multicolumn{2}{c|}{ PUBLIC } & \multicolumn{2}{c|}{ PRIVATE } \\
\hline & & Freq & $\%$ & Freq & $\%$ \\
\hline 1 & Staff development interview schedule & 1.91 & 0.95 & 2.89 & 0.73 \\
\hline 2 & $\begin{array}{l}\text { Questionnaire returned to the staff development } \\
\text { coordinator }\end{array}$ & 1.70 & 0.78 & 2.33 & 0.95 \\
\hline 3 & Staff annual appraisal report & 2.74 & 0.90 & 3.24 & 0.76 \\
\hline 4 & Training needs audit carried by consultants & 2.07 & 0.87 & 2.28 & 0.93 \\
\hline 5 & Use of staff development committee report & 2.28 & 0.79 & 2.68 & 0.87 \\
\hline 6 & Classroom observation by supervisors & 2.91 & 0.77 & 3.52 & 0.62 \\
\hline 7 & Ad hoc assessment by the principal & 2.88 & 0.81 & 3.39 & 0.74 \\
\hline 8 & Aggregate Mean & 2.36 & 0.55 & 2.90 & 0.51 \\
\hline
\end{tabular}

As shown in table 2, the mean weighting of respondents' assessments of the rate of utilization of the approaches fell into three categories, namely 2, 3 and 4 averages. Training needs audit and filling of questionnaire are minimally utilized in both public and private secondary schools (mean ranges between 1.70 and 2.33). The techniques that are moderately utilized in public schools are appraisal report, classroom observation and ad hoc assessment by the principal (mean approximate 3.0, indicating moderate usage). For the private schools, interview schedule, appraisal report, staff development committee report and ad hoc assessment by the principals are moderately utilized (the respective means range between 2.68 and 3.39).

The only technique that was assessed as highly utilized in private schools is classroom observation, with a mean of 3.52 , which is in the region of "strongly agreed" by the response made. On the aggregate average, these techniques are minimally utilized in public schools but moderately utilized in private schools with respective means of 2.0 and 2.9 . 
Hypothesis

There is no significant difference between public and private secondary schools with respect to the rate of utilization of the competency assessment techniques.

Table 3: $\mathrm{t}$ - test analysis on the rate of utilization of the competency assessment techniques by public and private schools.

\begin{tabular}{|l|l|l|l|l|l|l|l|}
\hline S/N & Variation Category & N & Mean & SD & t-test & 2-tailed Significance & Remarks \\
\hline 1 & Public School & 316 & 2.36 & .55 & -9.831 & .000 & Very Significant \\
\hline \multirow{2}{*}{2} & Private School & 2 & 2. & $\cdot$ & & & \\
& & & & & & & \\
& & & & & & & \\
\end{tabular}

How public secondary schools compare with private schools in the rate of utilization of competency assessment techniques is the focus of the hypothesis. The comparison of the extent of utilization of the techniques of public schools (mean $=2.36)$ and private secondary schools (mean $=2.90$ ) yielded a $t$-value of -9.831 . This $t-$ value is found to be significant at .000 which is far less than 0.05 at which the test was carried out.

Consequently, the deference was considered to be very significant and therefore the null hypothesis was rejected. The conclusion is that significant differences exist between public and private secondary schools in the extent to which they adopt competency assessment techniques for determining staff training needs. A closer look at Table 3 shows that the mean for private secondary schools (2.90) is higher than that of public secondary schools (2.36). This means that private schools significantly adopt competency assessment techniques more than public schools in evaluating their teaching staff for training.

\section{DISCUSSION}

The study shows that seven (7) approaches/techniques outlined are all utilized by both public and private secondary schools in determining the training needs of teachers. They are staff development, interview schedule, questionnaire returned to the staff development coordinator, staff annual appraisal report, training needs audit carried by consultants, staff development committee report, classroom observation by external supervisors and ad hoc assessment by the principal. However, classroom observation is the most utilized in both schools, but more in private schools. This practice therefore underlies the critical role of performance appraisal in determining the training needs of an organization's workforce. It is strategic in the process of ensuring performance improvement as highlighted by Nwachukwu (2000) that the need for performance appraisal is well recognized in all successful organizations. It helps to determine how effectively an employee's performance in carrying out the general duties of his or her role, together with specific targets with specific targets that have been set.

However, despite the importance of performance appraisal in the life of an organization in terms of employees' effectiveness and efficiency, significant difference exists between public and private schools with respect to the utilization frequency of the techniques. The result revealed that while the techniques are minimally utilized in public schools, they are moderately utilized in private schools. The implication therefore is that public schools which are owned and managed by the government give very little consideration to this all-important activity that is vital to the entire package of ensuring teacher effectiveness and efficiency. Such a situation has obvious implication for the training and development of public school teachers. This is because for the training and development programmes to be rational, they must be based on the identified needs. They must be need - based. Dessler (2008) therefore remarked that appraisal permits the boss and subordinates to develop a plan for correcting any deficiencies and to reinforce the things the subordinate does right. It also serves a useful career planning purpose. The strategy enables the manager to review the development needs of all employees. 


\section{CONCLUSION}

From the foregoing, it could be concluded that the critical role performance appraisal plays in the process of enhancing employees' performance is sacrosanct. Both the public and private secondary schools are conscious of this as evidenced in the utilization of different appraisal techniques. However, the utilization rate of the techniques is significantly different between the two schools, with the private showing more commitment.

\section{RECOMMENDATIONS}

Based on the findings of the study as stated above, the following recommendations are therefore made:

- The government in collaboration with the Teachers Registration Council of Nigeria (TRCN) should make the necessary legal provisions that will make it mandatory for all public and private schools to regularly appraise their teachers in order to identify their professional needs so that the training and development programmes provided will be based on needs.

- The government should provide a legal framework that coordinates and harmonizes educational practices in both schools to ensure standards and uniformity. The strict implementation of such legal provisions should be a priority.

- The Ministry of Education and the relevant agencies should make the necessary provisions for the training of personnel for competency assessment in their right quantities and quality.

- Performance appraisal as much as possible should be participatory and collaborative between the assessor and the appraisee to ensure openness and sincerity.

- Performance appraisal should be as confidential as possible and should be strictly for the professional development of the teachers.

\section{REFERENCES}

Anikulapo, J. O., 2007, May 20. Unqualified teachers in our schools. The Guardian Newspaper, 25, (789): 12.

Archer North Performance Appraisal System., 2010. Performance Appraisal www.performanceappraisals.com/intro.htm (accessed 18.5.11)

Chapman, A., 2011. Performance Appraisal http://www.businessballs.com/performan ce-appraisals.com/intro. htm (accessed 17.05.11)

Cole, G. A., 2002. Personal and human resources management. London: Bookpower.

Dessler, G. (2008). Human resource management. New Delhi: PrenticeHall

Nwachukwu, C. C., 2000. Human resource management. Port Harcourt, University of Port Harcourt press.

Obasi, K. K., 2011. Teacher performance appraisal and quality secondary education delivery: The planning challenges. African Journal of Educational Research and Development 4, (2): 217-223.

Rehman, S., 2009. Making teachers performance appraisal system effective. http@//www.chitraltoday.com/index.php? option=com_content\&amp.view=articles\& amp;id=(accessed 17.05.2011)

Sanders \& Rivers., 1996. Performance appraisal. http://www.edweek.org/images/rctopbarbg-inside.jpg (accessed 09.03.2010)

Santiago, P and Benavides, F., 2009. Teacher evaluation. www.oecd.Org/edu/teacherev aluationportgal (accessed 18.08.2010). 
Seanhan., 2010. Human resource management performance appraisal.htpp/studymode.c om/essay/Bus303-Human-ResourceManagement-Performance.

The elementary teachers federation of Ontario.,

2011. Teacher performance appraisal system. www.edu.gov.on.ca/.../appraise.html (Accessed 18.05.2011)

U S Department of Interior., 2004. Performance appraisal handbook.http://www.doi. gov.htm/guidance/370dm430hn(accesse d 26.11.2012)

Wikipedia. The Free Encyclopaedia., 2011. Performance appraisal.wikipedia.org/.../ performance-apprai...(accessed 17.05.2011)

Worcester Polytechnic Institute., 2010. Performance appraisal. http://www.wpi. edu/Admin/HR/performance-appraisalhtml. 